\title{
Mengurai Kerancuan Istilah Strategi dan Metode Pembelajaran
}

\author{
Ahwan Fanani \\ IAIN Walisongo Semarang \\ Email: aristifanfanani@yahoo.com
}

\begin{abstract}
This paper attempts to describe confused term of strategy and method learning. The key term in the field of education, especially in aspect learning, are approach, model, strategy, method, and technology. The five words have a conceptual distinction and two other terms cause confusion, i.e.: strategies and methods. Diversity and confusion of these terms occur both in learning practice and in the study of the theory. This study shows that the existence of the phenomenon of the use of the strategies and methods term that are relatively loose and even they are used interchangeable. There is no agreement in the literature that examined on applicative relationship between the two terms above. It was further confirmed that both terms have the same meaning field.
\end{abstract}

Keyword: learning, strategy, method, confusion

\begin{abstract}
Abstrak
Paper ini berusaha mengurai kerancuan istilah strategi dan metode pembelajaran. Istilah kunci dalam bidang pendidikan, khususnya dalam aspek pembelajaran, muncul istilah pendekatan, model, strategi, metode, dan teknik. Kelima istilah tersebut memiliki perbedaan konseptual dan dua istilah yang lain menimbulkan kerancuan, yaitu: strategi dan metode. Keberbedaan dan kerancuan dua istilah tersebut terjadi baik dalam praktik pembelajaran maupun dalam kajian teori. Kajian ini menunjukkan bahwa adanya fenomena penggunaan istilah strategi dan metode yang relatif longgar dan bahkan keduanya digunakan secara saling menggantikan. Istilah metode dan strategi belum disepakati penggunaannya namun memiliki medan pengertian yang sama.
\end{abstract}

Kata kunci: pembelajaran, strategi, metode, kerancuan 


\section{A. Pendahuluan}

Kesadaran mengenai kebutuhan terhadap cara yang representatif dalam pembelajaran saat ini semakin meningkat. Wina Sanjaya menyatakan bahwa salah satu masalah yang dihadapi dunia pendidikan nasional adalah lemahnya proses pembelajaran. Proses pembelajaran kurang merangsang kemampuan berpikir dan lebih menekankan hafalan informasi. Akibatnya, lahirlah siswa-siswa yang baik dalam penguasaan teori, tetapi lemah dalam aplikasi. ${ }^{1}$

Pada pasal 4 ayat (4) Undang-Undang Nomor 20 Tahun 2003 tentang Sistem Pendidikan Nasional menegaskan bahwa "Pendidikan diselenggarakan dengan memberi keteladanan, membangun kemauan, dan mengembangkan kreativitas peserta didik dalam proses pembelajaran." Dalam pendahuluan Permendiknas Nomor 41 Tahun 2007, disebutkan lebih lanjut bahwa "Proses pembelajaran pada setiap satuan pendidikan dasar dan menengah harus interaktif, inspiratif, menyenangkan, menantang, dan memotivasi peserta didik untuk berpartisipasi aktif serta memberikan ruang yang cukup bagi prakarsa kreativitas dan kemandirian sesuai dengan bakat, minat, dan perkembangan fisik serta psikologis peserta didik".

Undang-undang di atas mengisyaratkan bahwa dimensi "how" adalah salah satu dimensi penting dalam pembelajaran. Dimensi "how" tersebut merefleksikan cara bagaimana pembelajaran dilakukan untuk mencapai tujuan pembelajaran. Cara tersebut merupakan salah satu dimensi dalam pembelajaran karena setiap desain pembelajaran mengandung empat dimensi: 1) kompetensi, 2) materi, 3) cara, 4) evaluasi. ${ }^{2}$ Dengan demikian, cara menjadi salah satu dimensi yang tidak terpisahkan dalam pembelajaran.

Dewasa ini, berbagai cara berkembang dalam dunia pendidikan. Sebagian cara itu diberi label metode, strategi, teknik, model, dan juga pendekatan. Munculnya berbagai istilah tersebut menunjukkan adanya perhatian besar bagi pengembangan dimensi cara dalam pembelajaran. Akan tetapi, munculnya berbagai istilah di atas tidak jarang menimbulkan kerancuan. Hal itu terjadi karena

1 Wina Sanjaya, Strategi Pembelajaran Berorientasi Standar Proses Pembelajaran, (Jakarta: Kencana, 2012), hlm. v.

${ }^{2}$ Barmawie Munthe, Desain Pembelajaran, (Yogyakarta: CTSD IAIN Sunan Kalijaga, 2009), hlm. 51-64. 
istilah-istilah itu mengacu kepada dimensi yang sama, tetapi dilihat dengan sudut pandang dan titik tekan yang barangkali berbeda, bahkan tumpang tindih di antara istilah-istilah di atas.

Ada yang mencoba membedakan kelima istilah di atas dan tampak masuk akal pembedaannya, namun di tingkat praksis sulit dibedakan. Ada yang mencoba untuk memberikan ilustrasi yang menggambarkan relasi antar kelimanya, namun tidak mampu menjabarkan dalam hubungan yang nyata di antara istilah-istilah tersebut. Tulisan ini secara khusus akan mencoba menguraikan dua dari kelima istilah di atas, yaitu metode dan strategi. Kedua istilah tersebut dipilih karena keduanya paling banyak digunakan dan diacu oleh para praktisi di bidang pendidikan. Klarifikasi terhadap dua istilah di atas akan membantu untuk menguraikan kerancuan istilah-istilah lainnya.

\section{B. Antara metode dan strategi}

Istilah metode dan strategi adalah dua definisi dalam pembelajaran yang paling banyak menimbulkan kerancuan dan pertanyaan. Ada sebagian kalangan yang mengidentikkan kedua istilah tersebut, namun banyak juga yang membedakan antara keduanya. Banyak kalangan mencoba untuk memberi jawaban atas persoalan tersebut, akan tetapi tidak berarti polemik mengenai kedua istilah itu berhenti.

Keberadaan tulisan ini dimaksudkan untuk memberikan klarifikasi dan pemetaan terhadap penggunaan kedua istilah tersebut di kalangan pakar pendidikan. Maka dari itu, tulisan ini menggunakan pendekatan dalam membuat definisi yang lazim digunakan dalam logika, yaitu mencari substansi dan menjelaskannya dengan sifat khas. Pencarian itu dilakukan melalui karya para tokoh yang membahas mengenai kedua istilah tersebut. Kemudian dilihat substansi, sifat khas, dan relasi antara kedua istilah.

Oemar Hamalik menyatakan bahwa metode adalah Cara untuk menyampaikan materi pembelajaran dalam upaya mencapai tujuan kurikulum." Definisi tersebut menegaskan bahwa metode pembelajaran ialah 1) cara, 2) untuk menyampaikan, 3) materi pembelajaran, 4) sebagai upaya mencapai tujuan kurikulum. Ia 
menegaskan bahwa di dalam metode ada prosedur. ${ }^{3}$ Namun ia menyatakan bahwa istilah metode terlalu menekankan kegiatan guru. Sehingga untuk masa sekarang diganti dengan istilah strategi yang lebih menekankan kegiatan siswa.

Di sisi lain, Hamalik mengungkapkan definisi strategi pembelajaran yang berbeda dengan definisi metode di atas. Ia menyatakan bahwa strategi pembelajaran adalah metode dan prosedur yang ditempuh oleh siswa dan guru dalam proses pembelajaran demi mencapai tujuan instruksional berdasarkan materi pengajaran tertentu dan dengan bantuan unsur penunjang tertentu pula. ${ }^{4}$

Dalam definisi tersebut, Hamalik menegaskan bahwa substansi strategi adalah metode. Jika definisi ini disusun berdasarkan pola substansi/kelas dan dijelaskan dengan sifat pembeda, seperti definisi manusia adalah hewan yang berpikir atau definisi pisang adalah buah yang berbentuk lonjong berasa manis agak asam. Maka, definisi Hamalik di atas menyiratkan bahwa strategi masuk dalam kelas metode alias lebih sempit dibandingkan metode.

Jika inkonsistensi Hamalik dalam menjelaskan hubungan antara metode dan strategi diabaikan serta berpijak kepada pernyataannya. Strategi adalah metode dengan orientasi yang lebih menekankan partisipasi siswa, sehingga metode maupun strategi mengandung dimensi prosedur. Akan tetapi, perbedaannya adalah metode menekankan pendekatan teacher-centered (berpusat kepada guru), sedangkan strategi menekankan pendekatan studentcentered (berpusat pada siswa). Jika digambarkan dalam bagan, pendapat Hamalik tersebut dapat dipahami sebagai berikut:

3 Oemar Hamalik, Kurikulum dalam Pembelajaran, (Jakarta: Bumi Aksara, 2009), hlm. 26-27.

${ }^{4}$ Oemar Hamalik sebagaimana dikutip oleh Yatim Riyanto, Paradigma Baru Pembelajaran: Sebagai Referensi Bagi Guru/ Pendidik Dalam Implementasi Pembelajaran Yang Efektif Dan Berkualitas, (Jakarta: Kencana, 2010), hlm. 140. 
Bagan 1

Substansi, Unsur, dan Sasaran Strategi dan Metode menurut Oemar Hamalik

\begin{tabular}{lcccl}
\hline & Substansi & Unsur & Pendekatan & Obyek \\
\hline Metode & Cara & Prosedur & teacher & - \\
& & & Materi \\
& & & pentered & - Tujuan \\
& & & kurikulum \\
& & & & Materi \\
& & & student - & pembelajaran \\
Strategi & cara & Prosedur & & Tujuan \\
& & & & kurikulum \\
& & & & \\
& & & &
\end{tabular}

Dalam penjelasan Hamalik di atas, tidak banyak uraian mengenai apa saja unsur metode dan strategi. Secara tidak langsung, ia menegaskan bahwa unsur utama metode dan strategi adalah sama, yaitu prosedur pembelajaran untuk menyampaikan materi pembelajaran dan tujuan kurikulum.

Sedangkan Hamzah B. Uno mengemukakan ada hal yang sedikit berbeda. Ia mengartikan strategi pembelajaran sebagai "cara-cara yang digunakan oleh seorang pengajar untuk menyampaikan materi pembelajaran, sehingga akan memudahkan peserta didik menerima dan memahami mata pelajaran, yang pada akhirnya tujuan pembelajaran dapat dikuasainya di akhir kegiatan pembelajaran." "Secara umum definisi strategi pembelajaran yang dikemukakan Uno tersebut hampir mirip dengan definisi metode pembelajaran yang dikemukakan oleh Hamalik. Definisi Uno mengenai strategi, menegaskan bahwa strategi adalah: 1) cara, 2) untuk memahamkan siswa tentang, 3) materi pembelajaran, dan 4) untuk mencapai tujuan pembelajaran. Sebagaimana penjelasan Hamalik, Uno juga menyatakan bahwa metode pembelajaran lebih bersifat prosedural, yaitu berisi tahapan tertentu.

Namun Uno membedakan secara jelas antara strategi dan metode pembelajaran. Baginya, metode adalah cara untuk mencapai tujuan pembelajaran yang berisi tahapan atau prosedur pembelajaran. Sedangkan strategi lebih luas lagi, yakni mengandung penjelasan mengenai metode dan teknik. Teknik sendiri diartikan sebagai jalan, alat atau media yang digunakan

${ }^{5}$ Hamzah. B. Uno, Model Pembelajaran Menciptakan Proses Belajar Mengajar yang Kreatif dan Efektif, (Jakarta: Bumi Aksara, 2011), hlm. 2. 
oleh guru untuk mengarahkan kegiatan peserta didik ke arah tujuan yang ingin dicapai. Itu berarti teknik lebih berorientasi kepada media yang digunakan oleh guru. Dalam paragraf lain, Uno mengartikan teknik sebagai cara yang digunakan, yang bersifat implementatif. Definisi teknik ini lebih menekankan dimensi cara. Jika pada definisi awal teknik pembelajaran diartikan sebagai jalan atau media, maka pada definisi kedua diartikan sebagai cara yang bersifat implementatif, yang antara satu guru dengan guru lain berbeda. Pada akhirnya agak sulit untuk memahami definisi Uno mengenai teknik, tapi ia menegaskan bahwa strategi pembelajaran mengandung penjelasan mengenai metode dan teknik.

Bagan 2

Substansi, Unsur, dan Sasaran Strategi dan Metode menurut Hamzah Uno

\begin{tabular}{lllcl}
\hline & $\begin{array}{c}\text { Sub- } \\
\text { stansi }\end{array}$ & \multicolumn{1}{c}{ Unsur } & Pendekatan & \multicolumn{1}{c}{ Sasaran } \\
\hline Metode & Cara & Prosedur & - & - Memahamkan materi \\
& & & & $-\begin{array}{l}\text { Mencapai tujuan } \\
\text { pembelajaran }\end{array}$ \\
\hline Strategi & Cara & Metode & - & - Memahamkan materi \\
& & dan teknik & & pembelajaran \\
& & & & $-\begin{array}{l}\text { Mencapai tujuan } \\
\text { pembelajaran }\end{array}$ \\
\hline
\end{tabular}

Dari tabel di atas tampak bahwa ada persamaan mendasar antara strategi menurut pengertian Uno dengan metode dalam pengertian Hamalik. Pertama, definisi yang mereka gunakan untuk dua istilah berbeda tersebut mengandung konsep-konsep yang sama. Kedua, Uno dan Hamalik memandang bahwa substansi metode atau strategi adalah cara. Sasaran yang mereka pahami juga hampir sama.

Perbedaan keduanya adalah menyangkut aspek pembeda antara metode dan strategi. Ada perbedaan dalam melihat hal yang membuat metode dan strategi memiliki kekhasan. Bagi Hamalik metode dan strategi adalah identik, yang membedakan hanyalah pendekatannya. Sedangkan bagi Uno strategi dan metode beda, yang membedakan adalah metode dan teknik masuk sebagai bagian strategi. Kesimpulannya, bagi Hamalik metode sejajar dengan strategi dan hanya dibedakan dengan pendekatan, sebaliknya bagi Uno metode adalah subordinat strategi. 
Hal itu diperjelas dengan komponen strategi pembelajaran yang dikemukakan oleh Uno yang mengutip dan menjabarkan pendapat Dicky dan Carey yang menyebutkan bahwa terdapat lima komponen strategi pembelajaran, yaitu: 1) kegiatan pembelajaran pendahuluan, 2) penyampaian informasi, 3) partisipasi peserta didik, 4) tes, dan 5) kegiatan lanjutan (tidak lanjut). ${ }^{6}$ Semua itu menggambarkan langkah-langkah dalam RPP. Jika diilustrasikan maka hubungan metode dan strategi dapat dijelaskan sebagai berikut:

Kerangka RPP

1. Identitas Mata Pelajaran

2. Kompetensi

3. Tujuan Pembelajaran

4. Materi

5. Strategi

6. Media

7. Langkah-Langkah

a. Langkah Pendahuluan

b. Langkah Inti mengandung metode strategi pembelajaran

c. Langkah Penutup

8. Evaluasi

9. Sumber Belajar

Apa yang dikemukakan Uno mengisyaratkan bahwa ia memandang metode sebagai bagian dari strategi, namun lingkup keduanya terbatas dalam langkah-langkah pembelajaran.

Pengertian lain mengenai strategi dan metode dikemukakan oleh Ismail. Ismail dalam bukunya Strategi Pembelajaran Agama Islam Berbasis PAIKEM memberikan beberapa penjelasan menyangkut hubungan metode dan strategi. Ismail menjelaskan bahwa strategi, metode, metodologi, pendekatan, teknik, dan prosedur menunjuk kepada arti sejenis, namun masing-masing memiliki titik tekan sendiri-sendiri. Ia mendefinisikan metode sebagai: "cara atau jalan yang ditempuh yang sesuai dan serasi untuk menyajikan suatu hal sehingga akan tercapai tujuan pembelajaran yang efektif dan efisien sesuai yang diharapkan."7 Dari definisi di atas, Ismail juga sepakat bahwa substansi metode

${ }^{6}$ Uno, Model pembelajaran..., hlm. 3.

7 Ismail, Strategi Pembelajaran Agama Islam Berbasis PAIKEM, (Semarang: Rasail, 2008), hlm. 8. 
adalah "cara." Unsur-unsur definisi metode menurut versi Ismail mencakup: 1) cara atau jalan, 2) untuk menyajikan, 3) suatu hal, 4) untuk mencapai tujuan pembelajaran, 5) secara efektif dan efisien.

Definisi metode menurut Ismail ini sama dengan dikemukakan oleh Hamalik maupun definisi strategi menurut Uno. Bedanya, Ismail memberikan alternatif substansi, yaitu jalan dan menambahkan kriteria efektif dan efisien. Substansi metode sebagai "jalan," sebagai alternatif "cara" tersebut sebenarnya malah mengaburkan kejelasan substansi, karena cara dan jalan memiliki konotasi yang berbeda. Istilah jalan tersebut bisa dipahami jika dikaitkan dengan penerjemahan kata metode ke dalam bahasa Arab, karena bahasa Arab metode adalah thariqah, yang secara bahasa berarti jalan. Namun, konotasi jalan sebagai cara lebih tepat digunakan dalam konteks keagamaan sebagai bahasa metaforis.

Ismail membedakan antara metode dan strategi. Menurutnya, strategi adalah "gambaran mengenai langkah-langkah yang akan ditempuh atau dijalankan" atau "cara-cara yang khusus dan jitu." Jadi, strategi bisa dipahami sebagai gambaran langkah (tahap/prosedur) dan cara. Sekilas definisi strategi tersebut sama dengan metode. Namun, ia kemudian menegaskan bahwa metode terkait langsung dengan proses pembelajaran, sedangkan strategi mengatur ketepatan penggunaan metode dalam pembelajaran. Ia menyamakan antara strategi dan teknik, tanpa ada penjelasan tentang perbedaan antara keduanya.

\section{Bagan 3}

Substansi, Unsur, dan Sasaran Strategi dan Metode menurut Ismail

\begin{tabular}{|c|c|c|c|c|}
\hline & Substansi & Unsur & Pendekatan & Sasaran \\
\hline Metode & $\begin{array}{l}\text { Cara } \\
\text { Jalan }\end{array}$ & - & - & $\begin{array}{l}\text { - mencapai tujuan } \\
\text { pembelajaran }\end{array}$ \\
\hline Strategi & $\begin{array}{l}\text { Cara/ } \\
\text { Gambaran } \\
\text { langkah }\end{array}$ & - & - & $\begin{array}{l}\text { - mengatur ketepatan } \\
\text { penggunaan } \\
\text { metode } \\
\text { - mencapai tujuan } \\
\text { pembelajaran }\end{array}$ \\
\hline
\end{tabular}

\footnotetext{
${ }^{8}$ Ismail, Strategi pembelajaran ..., hlm. 24.
} 
Meskipun ia menjelaskan perbedaan antara strategi dan metode, namun agak sulit sebenarnya melihat praksis dari perbedaan tersebut. Ia mencontohkan beberapa metode pembelajaran, yaitu ceramah, tanya jawab, diskusi, eksperimen, demonstrasi, pemberian tugas, sosiodrama, latihan (drill), kerja kelompok, proyek, problem solving, team teaching, karyawisata, simulasi, dan lain-lain. Ia mencontohkan strategi seperti everyone is teacher here, reading aloud, information search, reading guide, active debate, role play, team quiz, dan lain-lain. Sekilas ada perbedaan yang menjadi bagian kategori metode dan bagian strategi, namun sulit dicari alasan perbedaan kelompok yang menjadi bagian metode dan strategi. Ada metode dan strategi yang identik, seperti metode sosiodrama dan strategi role play atau metode diskusi dengan strategi diskusi kelompok.

Sebagai pembanding, perlu kiranya pendapat Wina Sanjaya dikemukakan di sini. Ia mengutip J.R. David yang menyatakan bahwa strategi adalah a plan, method, or series of activities designed to achieved particular educational goal (sebuah rencana, metode, atau serangkaian kegiatan yang dirancang untuk mencapai tujuan pendidikan tertentu). ${ }^{9}$ Sanjaya kemudian menyimpulkan bahwa strategi pembelajaran adalah "perencanaan yang berisi tentang rangkaian kegiatan yang didesain untuk mencapai tujuan pendidikan tertentu." Kesimpulan Sanjaya tersebut secara garis besar hampir sama dengan J.R. David, tetapi ada perbedaannya. Definisi David meletakkan rencana, metode, dan rangkaian kegiatan sejajar dan sederajat karena dipisahkan dengan konjungsi or (atau), tetapi dalam kesimpulan Sanjaya rangkaian kegiatan dikatakan sebagai isi dari rencana atau menjadi subordinat rencana.

Definisi David berbeda dengan definisi Uno dan Hamalik yang memasukkan strategi dalam kelas "cara." Definisi David memasukkan strategi dalam kelas rencana, kelas metode (seperti versi lain Hamalik di atas), atau kelas kegiatan. Namun pada akhirnya, Sanjaya memilih untuk memasukkan strategi pembelajaran dalam kelas rencana, sehingga ia menegaskan adalah 1) rencana tindakan (a plan of operation achieving something) yang mencakup penggunaan metode dan pemanfaatan berbagai

\footnotetext{
${ }^{9}$ Sanjaya, Strategi pembelajaran ..., hlm. 126.
} 
sumber daya 2) untuk mencapai tujuan tertentu. Jadi, substansi dari strategi pembelajaran adalah perencanaan, bukan pada penerapan.

Dalam perspektif Sanjaya terdapat hal yang membedakan antara pengertian strategi dan metode. Ia mengartikan metode sebagai "cara yang dapat digunakan untuk melaksanakan strategi (a way in achieving something)." ${ }^{.10}$ Dari pembedaan di atas, jelas bahwa Sanjaya menempatkan strategi dalam posisi lebih luas dibandingkan metode dan metode menjadi bagian strategi.

\section{Bagan 4}

Substansi, Unsur, dan Sasaran Strategi dan Metode menurut Wina Sanjaya

\begin{tabular}{|c|c|c|c|c|}
\hline & Substansi & Unsur & Pendekatan & Sasaran \\
\hline Metode & Cara & - & - & $\begin{array}{l}\text { melaksanakan } \\
\text { strategi }\end{array}$ \\
\hline Strategi & $\begin{array}{l}\text { Rencana } \\
\text { tindakan }\end{array}$ & $\begin{array}{l}\text { - Rangkaian } \\
\text { kegiatan } \\
\text { - Metode } \\
\text { pemanfaatan } \\
\text { sumber daya }\end{array}$ & - & $\begin{array}{l}\text { mencapai tujuan } \\
\text { pendidikan }\end{array}$ \\
\hline
\end{tabular}

Selain strategi, Sanjaya juga menggarisbawahi adanya perbedaan metode dan teknik. Teknik baginya adalah cara untuk mengimplementasikan metode. Sementara itu, taktik adalah gaya seseorang dalam menerapkan metode dan teknik. Pembedaan antara teknik dan taktik ini sebenarnya justru memperumit keadaan. Di dalam strategi ada cara penerapan yang disebut metode. Dalam metode ada lagi cara penerapannya yang disebut teknik. Dalam metode dan teknik ada gaya pelaksanaan yang disebut taktik.

Jadi, Sanjaya memahami strategi sebagai sebuah kerangka umum saja. Hal itu membuat strategi bisa dijabarkan dalam banyak metode. Ia mencontohkan strategi pembelajaran expository dapat dijalankan dengan metode ceramah, tanya jawab, dan diskusi. Baginya, strategi hanya terbagi menjadi tiga, yaitu: 1) strategi penyampaian penemuan (exposition-discovery learning), 2) strategi pembelajaran kelompok, dan 3) strategi pembelajaran

${ }^{10}$ Sanjaya, Strategi pembelajaran ..., hlm. 127. 
individu. ${ }^{11}$ Namun pada bab-bab selanjutnya, ia memberikan beberapa strategi lain dengan penjabarannya, seperti:

1. Strategi pembelajaran berorientasi aktivitas siswa, yaitu pendekatan dalam pembelajaran yang menekankan kepada aktivitas siswa secara optimal untuk memperoleh hasil belajar berupa perpaduan antara aspek kognitif, afektif, dan psikomotor secara seimbang. Uraian mengenai strategi ini menjadi rancu dengan pendekatan pembelajaran.

2. Strategi pembelajaran espositori (direct instruction), yaitu strategi pembelajaran yang menekankan proses penyampaian materi secara verbal. Strategi ini menekankan pembelajaran yang bersifat teacher-centered (pembelajaran berbasis guru).

3. Strategi pembelajaran inquiri, yaitu rangkaian kegiatan pembelajaran yang menekankan proses berpikir secara kritis dan analitis untuk mencari dan menemukan sendiri jawaban dari suatu masalah yang dipertanyakan.

4. Strategi pembelajaran berbasis masalah (SPBM), yaitu rangkaian aktivitas pembelajaran yang menekankan kepada proses penyelesaian masalah yang dihadapi secara ilmiah. Beda dengan strategi pembelajaran inquiry (SPI) ialah terkait masalah dalam SPBM bersifat terbuka dan belum ada jawaban pasti, sedangkan dalam SPI masalahnya tertutup dan telah ada jawabannya.

5. Strategi pembelajaran peningkatan kemampuan berpikir, yaitu "model" pembelajaran yang bertumpu kepada pengembangan kemampuan berpikir siswa melalui telaah fakta-fakta atau pengalaman anak sebagai bahan untuk memecahkan masalah yang diajukan. Oleh sebab itu, pemahaman strategi bertumpang tindih dengan model.

6. Strategi pembelajaran kooperatif, yaitu rangkaian kegiatan belajar yang dilakukan siswa dalam kelompok-kelompok tertentu untuk mencapai tujuan pembelajaran yang dirumuskan. Sehingga ia menyebut pembelajaran kooperatif sebagai model, meskipun pada subjudulnya disebut strategi.

7. Strategi pembelajaran kontekstual, yaitu suatu strategi pembelajaran yang menekankan kepada proses keterlibatan siswa secara penuh untuk dapat menemukan materi yang dipelajari dan menghubungkannya dengan situasi kehidupan

${ }^{11}$ Sanjaya, Strategi pembelajaran ...., hlm. 128. 
nyata sehingga mendorong siswa untuk dapat menerapkannya dalam kehidupan mereka. Di sini, Sanjaya juga menyebut strategi ini sebagai pendekatan.

8. Strategi pembelajaran afektif. Sanjaya tidak memberikan definisi yang jelas, namun ia menyebutkan dua model strategi pembelajaran sikap, yaitu model konsiderasi dan model pengembangan kognitif. ${ }^{12}$

Pemetaan Sanjaya terhadap berbagai strategi pembelajaran di atas mengandung banyak persoalan. Pertama, ia secara tegas mengategorikan strategi sebagai rencana, namun definisi terhadap berbagai strategi di atas menunjukkan bahwa ia juga mengartikan strategi sebagai kegiatan. Ia terkadang mendefinisikan sebuah strategi sebagai pendekatan atau model. Hal itu menunjukkan meskipun ada kejelasan konsepsi mengenai strategi dan metode, pada penerapannya tetap tidak mudah untuk membuat batas demarkasi antara kedua konsep tersebut. Akibatnya, pada prakteknya terjadi tumpang tindih.

Ada penjelasan lain mengenai strategi pembelajaran yang juga memosisikan strategi sebagai kerangka umum atau perencanaan, sebagaimana dikemukakan oleh Newman dan Morgan. Sebagaimana dikutip oleh Segala, memetakan unsur strategi pembelajaran ke empat hal: ${ }^{13}$

1. Pengidentifikasian dan penetapan spesifikasi dan kualifikasi hasil yang harus dicapai dan menjadi sasaran usaha tersebut, dengan mempertimbangkan aspirasi masyarakat yang memerlukannya.

2. Pertimbangan dan pemilihan pendekatan utama yang ampuh untuk mencapai sasaran.

3. Pertimbangan dan penetapan langkah-langkah yang ditempuh sejak awal sampai akhir.

4. Pertimbangan dan penetapan tolok ukur dan ukuran baku yang akan digunakan untuk menilai keberhasilan usaha yang dilakukan.

Ada pula yang mengajukan unsur-unsur strategi pembelajaran secara lebih luas, serta menyiratkan bahwa strategi pembelajaran

${ }^{12}$ Sanjaya, Strategi pembelajaran ...., hlm. 137, 179, 196, 214, 226-227, 241, 255, dan 277-278.

${ }^{13}$ Syaiful Sagala, Konsep dan Makna Pembelajaran untuk Membantu Memecahkan Problematika Belajar dan Mengajar, (Bandung: Alfabeta, 2012), hlm. 222. 
merupakan kerangka umum atau rencana pembelajaran. ${ }^{14}$ Unsurunsur yang lazim terdapat dalam rumusan strategi pembelajaran adalah:

1. Tujuan umum pembelajaran yang ingin dicapai, misalnya meningkatnya minat membaca, meningkatnya motivasi untuk belajar matematika.

2. Teknik, yaitu berbagai macam cara yang dapat dilakukan untuk mencapai tujuan umum. Pada umumnya merupakan penggabungan dari beberapa teknik sekaligus, misalnya ceramah, mendongeng, simulasi, dan permainan.

3. Pengorganisasian kegiatan belajar mengajar meliputi pengorganisasian mahasiswa, dosen, dan tenaga kependidikan lain. pengorganisasian dosen bisa dilakukan secara beregu, sendiri atau bergantian. sedang pengorganisasian tenaga kependidikan adalah bilamana ada tenaga-tenaga khusus seperti konselor, pengembang pembelajaran, pustakawan, teknisi sumber belajar yang dilibatkan dalam suatu kerja sama tim.

4. Peristiwa pembelajaran, yaitu tahapan dalam melaksanakan proses pembelajaran termasuk usaha yang perlu dilakukan dalam tiap tahap agar proses itu berhasil. secara garis besar meliputi langkah-langkah: a) persiapan, b) penyajian, c) pemantapan.

5. Urutan belajar, yaitu penahapan isi ajaran yang diberikan agar lebih mudah dipahami. kemungkinan urutan adalah dari yang mudah ke yang sukar, dari yang sudah diketahui ke hal yang baru, dari yang konkret ke yang abstrak, dari yang sederhana ke yang rumit, dari keseluruhan ke rincian, dari permulaan sampai akhir, dari yang lampau ke yang akan datang (kronologis), dari dalil ke contoh atau sebaliknya, atau dari pengindraan ke pemikiran.

6. penilaian, yaitu dasar dan alat (instrumen) yang digunakan untuk mengukur usaha dan atau hasil belajar.

7. pengelolaan kegiatan belajar atau kelas, yaitu meliputi bagaimana pola pembelajaran diselenggarakan, apakah dengan pola klasikal guru siswa, pola klasikal media, pola

${ }^{14}$ Yusufhadi Miarso, Menyemai Benih Teknologi Pendidikan, (Jakarta: Kencana, 2007), hlm. 532-534. 
interaksi perorangan, pola mandiri, pola saling ajar, atau pola media interaktif.

8. tempat atau latar adalah lingkungan di mana proses belajar mengajar berlangsung.

9. waktu: jumlah dan saat jadwal berlangsungnya proses belajar mengajar. ${ }^{15}$

Penjabaran mengenai strategi pembelajaran ini benar-benar utuh dan komprehensif yang mencakup hampir semua unsur pembelajaran. Seolah strategi pembelajaran adalah rancangan unsur-unsur pembelajaran. Dalam rancangan ini, beberapa hal yang biasanya dimasukkan sebagai metode pembelajaran hanya dimasukkan sebagai teknik pembelajaran, misalnya ceramah, bercerita, simulasi, dan permainan (game). Strategi pembelajaran dalam pengertian berikut tampak seperti kerangka RPP, atau gambaran seluruh proses pembelajaran mulai dari tujuan pembelajaran hingga evaluasi, minus identitas mata pelajaran.

Namun, pengertian strategi pembelajaran sebagai kerangka pembelajaran yang bersifat global tersebut masih belum sepenuhnya disepakati semua pihak. Ismail misalnya, meskipun setuju untuk mengartikan strategi sebagai gambaran umum, namun contoh-contoh strategi pembelajaran yang dikemukakan bersifat praktis. Ia mengemukakan berbagai strategi yang bisa juga disebut metode. Dalam hal ini, Ismail juga tidak sendiri. Ada Mel Silberman yang menulis buku 101 Strategies to Teach Any Subject (101 strategi untuk mengajarkan mata pelajaran atau kuliah) atau Hisyam Zaini, Bermawie Munthe, dan Sekar Ayu Aryani yang menulis buku Strategi Pembelajaran Aktif, yang di dalamnya menyajikan 45 strategi untuk membelajarkan, yang sebagian juga ada dalam buku Ismail, dan strategi untuk melakukan proses evaluasi pembelajaran. Dalam buku tersebut, ceramah pun dimasukkan sebagai strategi pembelajaran. ${ }^{16}$

Barmawie Munthe sendiri kemudian menulis satu subbab sendiri dalam bukunya yang lain Desain Pembelajaran. Ia menegaskan bahwa desain pembelajaran berisi empat unsur, yaitu 1) desain kompetensi, 2) desain materi, 3) desain strategi pembelajaran, dan 4) desain evaluasi. Ia memasukkan desain

${ }^{15}$ Miarso, Menyemai Benih ..., hlm. 528-535.

${ }^{16}$ Hisyam Zaini, Bermawie Munthe, dan Sekar Ayu Aryani, Strategi Pembelajaran Aktif, (Yogyakarta: CTSD IAIN Sunan Kalijaga, 2005), hlm. 54 
strategi pembelajaran sejajar dengan desain kompetensi, desain materi, dan desain evaluasi yang berarti desain strategi pembelajaran hanyalah salah satu dari proses pembelajaran yang dimulai dari perencanaan sampai evaluasi. Jadi, strategi digunakan dalam pengertian yang sama dengan metode pembelajaran sehingga ia pun menuliskan strategi dengan garis miring metode (strategi/metode). Ia mendorong agar digunakan strategi pembelajaran aktif, sebagai alternatif dari strategi ceramah. Desain strategi pembelajaran dipandang sebagai cara seorang guru atau dosen untuk melakukan usaha nyata untuk tercapainya kompetensi. ${ }^{17}$

Dalam buku-buku pedoman Pekerti yang dikeluarkan oleh Dirjen Diktis Departemen Pendidikan Nasional tahun 2005, tidak ditemukan buku petunjuk yang menjelaskan tentang strategi pembelajaran. Yang ada adalah buku-buku pedoman tentang model pembelajaran dan metode instruksional, yaitu metode untuk mencapai tujuan pembelajaran. ${ }^{18}$ Ketiadaan buku pedoman mengenai strategi ini menunjukkan bahwa metode dipandang telah mewakili aspek "cara" dalam pembelajaran.

Hal itu barangkali yang mendorong Hamalik untuk menyimpulkan bahwa metode sama dengan strategi, atau istilah strategi adalah istilah yang saat ini digunakan untuk mengacu kepada pengertian metode. Strategi diturunkan dari model pembelajaran. ${ }^{19}$ Ia mencontohkan beberapa strategi pembelajaran yang menjabarkan model interaksi sosial, yaitu: kerja kelompok, pertemuan kelas, pemecahan masalah sosial, model laboratorium, model pengajaran yurisprudensi, bermain peran, dan simulasi sosial. Strategi kerja kelompok dan pemecahan masalah ini sama dengan strategi yang dikemukakan oleh Sanjaya di atas. Namun, bermain peran atau simulasi sosial sama dengan metode instruksional yang dikemukakan oleh Buku Pedoman Pekerti. ${ }^{20}$

${ }^{17}$ Munthe, Desain pembelajaran ..., hlm. 51-64.

${ }^{18}$ Lihat Udin S. Winataputra, Model-Model Pembelajaran Inovatif, (Jakarta: PAU PPAI, 2005), dan Lily Budiharjo, Hakikat Metode Instruksional, (Jakarta: PAU-PPAI Universitas Terbuka, 2005), hlm. 76.

${ }^{19}$ Hamalik, mengikuti buku pedoman, juga membagi model pembelajaran menjadi empat: 1) model interaksi sosial, 2) model proses informasi, 3) model personal, dan 4) model modifikasi tingkah laku, Lihat Oemar Hamalik, Kurikulum dalam Pembelajaran ..., hlm. 127-130.

${ }^{20}$ Lily Budiharjo, Hakikat Metode Instruksional ..., hlm. 14-27. 
Penggunaan istilah metode dan strategi secara saling menggantikan juga digunakan oleh Crawford, Saul, Matthews, dan Makinster. Mereka menulis buku dengan judul Teaching and Learning Strategies for Thinking Classroom. Dalam buku tersebut istilah metode dan strategi digunakan secara bergantian dengan pengertian yang sama. Pada bab (section) kedua terdapat bab dengan judul bab teaching methods and strategies (metode dan strategi pengajaran). Pada bab tersebut istilah metode dan strategi digunakan secara saling menggantikan sehingga pada paragraf pertama ada kalimat: "Pengajaran lebih dari hanya seperangkat metode," sedangkan pada paragraf ketiga disebutkan: "Meski pengajaran lebih dari seperangkat strategi, namun ada beberapa metode pembelajaran yang harus menjadi bagian dari perbendaharaan guru yang kreatif." 21

Ada yang menggunakan istilah metode secara lebih luas dibandingkan strategi. Liu dan Shi, sebagaimana dikutip oleh Peter Westwood, mendefinisikan metode pembelajaran sebagai seperangkat prinsip, prosedur, atau strategi yang diterapkan oleh guru untuk mencapai pembelajaran yang diinginkan dari siswa. ${ }^{22}$ Westwood bahkan menggunakan istilah pendekatan dan metode dalam pengertian yang sama. Pada bab ketiga, misalnya, ia memberi judul subbabnya dengan student-centered methods, kemudian ia beri subbab lagi dengan sebutan student-centered approaches. $^{23}$

Dari berbagai pengertian di atas tidak mudah untuk membuat kesimpulan mengenai perbedaan strategi dan metode. Pertama, ada yang memahami bahwa strategi dan metode merupakan cara. Namun, strategi lebih luas dan mengandung metode di dalamnya. Pendapat ini dianut oleh Hamzah Uno, Newman dan Morgan. Syaiful Sagala, dan Ismail. Kedua, ada yang memahami strategi sebagai rencana, dan metode adalah cara pelaksanaannya, sebagaimana dianut oleh Sanjaya. Ketiga, ada yang memahami strategi sebagai payung bagi teknik pembelajaran, sebagaimana dianut oleh Yusufhadi Miyarso. Keempat, ada yang memahami

${ }^{21}$ Crawford, Alan E., Teaching and Learning Strategies for Thinking Classroom, (New York: The International Debate Education Association, 2005), hlm. 10.

${ }^{22}$ Peter Westwood, What Teachers Need to Know about Teaching Methods, (Victoria: ACER Press, 2008), hlm. v.

${ }^{23}$ Westwood, What Teachers ..., hlm. 26. 
strategi sebagai metode dan kedua istilah tersebut digunakan secara saling menggantikan, sebagaimana dianut oleh Oemar Hamali dan Crawford, Saul, Matthews, dan Makinster. Penganut pendapat ini termasuk juga Mell Siberman. Kelima, ada pula yang memasukkan strategi sebagai subordinat metode, seperti dilakukan oleh Liu dan Shi, sebagaimana dikutip dan disetujui oleh Peter Westwood.

Sampai tahap ini belum tercapai konsensus mengenai batasan strategi dan metode di kalangan pakar pendidikan. Hal itu bisa dipahami mengingat keduanya mengacu kepada obyek yang sama atau kurang lebih sama. Ada kemungkinan bahwa kedua istilah itu awalnya digunakan oleh orang berbeda untuk menyebut realitas yang sama dan kemudian tidak ada keterangan sehingga menimbulkan kerancuan. Upaya untuk membedakan kedua istilah itu telah diusahakan para ahli. Ada kalanya pembedaan itu tampak baik, namun kurang operasional. Persoalannya adalah apabila istilah strategi diartikan secara luas, ia akan tumpang tindih dengan model. Apabila istilah strategi diartikan secara spesifik sebagai cara atau langkah untuk melakukan kegiatan pembelajaran, maka strategi tumpang tindih dengan metode. Akan lebih mudah apabila istilah strategi dan metode dianggap identik sehingga tidak menimbulkan problem istilah yang tidak perlu.

Penggunaan istilah strategi dan metode secara identik tersebut bisa juga dilihat dalam buku The Methods for Teaching: Promoting Student Learning in K-2 Classroom karya Jacobsen, Eggen, dan Kauchak. ${ }^{24}$ Mereka memberi judul pada buku mereka dengan Methods, tetapi dalam uraian metode-metode pembelajaran, ia menyebut dengan istilah strategi, seperti strategistrategi bertanya, strategi ceramah, strategi diskusi, strategi pembelajaran berbasis masalah, dan strategi-strategi dalam yang masuk dalam kelompok pembelajaran kooperatif (investigasi kelompok, student teams achievment division, dan jigsaw).

${ }^{24}$ David A. Jacobsen, Paul Eggen, dan Donald Kauchak, Methods for Teaching: Metode-Metode Pengajaran, Meningkatkan Belajar Siswa TKSMA, terj. Achmad Fawaid dan Khoirul Anam, (Yogyakarta: Pustaka Pelajar, 2009), hlm. 56. 


\section{Problem Pendefinisian}

Kerancuan dan ketidakseragaman dalam pemberian definisi mengenai strategi dan metode tersebut lahir dari problem definisi. Definisi untuk memahami sebuah obyek. Semakin kompleks obyek yang harus didefinisikan, semakin diperlukan definisi yang sempurna. Dalam logika tradisional, definisi dibagi tingkatannya menurut unsur pembentuk definisi. Definisi yang paling sederhana adalah definisi nominal, yaitu definisi yang hanya dilakukan menjelaskan satu pengertian dengan pengertian lain yang umum diketahui orang. Tingkatan yang lebih tinggi adalah definisi aksidentil, yaitu definisi yang disusun dari genus dan sifat khusus (propria), yaitu tanda pengenal yang dimiliki oleh entitas tertentu yang tidak permanen. Tingkatan tertinggi dari definisi adalah definisi esensial, yaitu definisi yang mengandung unsur genus dan diferensial, yaitu tanda pengenal yang menunjukkan hakikat suatu entitas. $^{25}$

Selama ini pembedaan terhadap istilah metode dan strategi tidak cukup dielaborasikan secara memadai. Definisi keduanya sering bertumpang tindih sehingga sulit membedakan esensi keduanya. Upaya-upaya untuk menjabarkan semua strategi dan metode selama ini masih belum berhasil dalam membedakan secara konklusif antara kedua istilah di atas. Penjelasan operasional keduanya belum memadai untuk melihat hubungan keduanya dalam praktek pembelajaran.

Jika sulit untuk dibuat definisi yang berdaya cakup (jami') dan berdaya beda (mani'), ada baiknya kedua istilah tersebut dipergunakan secara saling menggantikan. Selama tidak ada penjabaran konseptual dan operasional yang memadai, pembedaan dan penciptaan istilah alih-alih akan mempermudah penjelasan realitas, bahkan bisa menjadi perangkap yang mempersulit pemahaman. Ada baiknya dilakukan penyederhanaan istilah, sehingga istilah yang tidak perlu dibedakan, sebaiknya dapat tidak dibedakan. Jalan lain adalah perlunya kesepakatan bersama mengenai istilah-istilah tersebut di kalangan para akademisi dan pakar pendidikan, agar istilah tersebut memiliki bobot ilmiah yang akan menunjang bobot praksisnya.

${ }^{25}$ Lihat M. Joesoef Souyb, Logika: Kaidah Berpikir secara Tepat, (Jakarta: al-Husan Zikra, 1997), hlm. 32-45. 
Penyamaan strategi dan metode tersebut dikuatkan dengan level pembelajaran yang disampaikan oleh Edward Anthony dalam konteks pembelajaran bahasan. Anthony membagi level pembelajaran menjadi tiga, yaitu: pendekatan (approach), metode (method), dan teknik (technique). Ketiganya ia sebut sebagai level konseptualisasi dan organisasi. ${ }^{26}$ Jika digambarkan dalam bagan, level pembelajaran versi Anthony adalah sebagai berikut:

\section{Bagan 5}

Level Pembelajaran menurut Edward Anthony
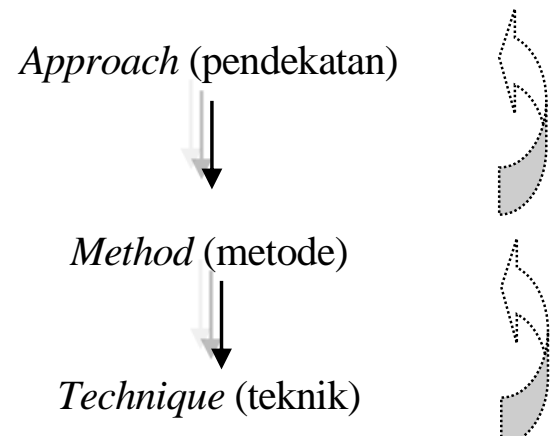

Gambar di atas menunjukkan bahwa metode merupakan penjabaran dari pendekatan, dan teknik adalah penjabaran dari metode. Pada saat yang sama, metode harus mengacu kepada pendekatan dan teknik juga harus dalam bingkai metode.

Pendekatan diartikan oleh Anthony sebagai seperangkat asumsi yang terkait dengan sifat dasar pembelajaran bahasa. Metode dimaknai sebagai rencana umum untuk menyajikan bahan kebahasaan secara tertib. Begitu pula, teknik diartikan sebagai trik tertentu yang dipergunakan di kelas untuk mencapai tujuan langsung. Teknik ini harus sejalan dengan metode. ${ }^{27}$ Jadi, menurut Anthony hanya ada tiga level organisasi dan konseptualisasi pembelajaran, yaitu pendekatan, metode, dan teknik. Seolah strategi pembelajaran adalah rancangan unsur-unsur pembelajaran. Dalam rancangan ini, beberapa hal yang biasanya dimasukkan sebagai metode pembelajaran hanya dimasukkan sebagai teknik

${ }^{26}$ Edward Anthony sebagaimana dikutip oleh Jack C. Richard dan Theodore S. Rodgers, Approaches and Methodes in Language Teaching, (Cambridge: Cambridge University Press, 1999), hlm. 15.

27 Sebagaimana dikutip Richard dan Rodgers, Approaches and Methodes ..., hlm. 15. 
pembelajaran, misalnya ceramah, bercerita, simulasi, dan permainan (game). Strategi pembelajaran dalam pengertian berikut tampak seperti kerangka RPP, atau gambaran seluruh proses pembelajaran mulai dari tujuan pembelajaran hingga evaluasi, minus identitas mata pelajaran.

Namun, pengertian strategi pembelajaran sebagai kerangka pembelajaran yang bersifat global tersebut masih belum sepenuhnya disepakati semua pihak. Ismail misalnya, meskipun setuju untuk mengartikan strategi sebagai gambaran umum, namun contoh-contoh strategi pembelajaran yang dikemukakan bersifat praktis. Level organisasi ini lebih mudah dijabarkan dalam praktek dibandingkan level yang lebih banyak, dengan membedakan strategi dan metode, tetapi pada pelaksanaannya tumpang tindih. Pembedaan istilah strategi dan metode tidak lagi memiliki relevansi teoritis maupun praktis.

\section{Penutup}

Konsep dan istilah dalam keilmuan menjadi kunci bagi pemahaman sebuah persoalan. Sebuah konsep dapat dijabarkan melalui definisi yang menjelaskan apa substansi dan apa ciri khas dari sebuah konsep. Istilah metode dan strategi mengandung konsep masing-masing. Persoalannya adalah konsep tersebut bersifat konstruktif, artinya dirumuskan berdasarkan pemahaman mengenai substansi dan sifat khasnya. Selama ini, konsep yang dikandung oleh istilah strategi dan metode dalam konteks pembelajaran menimbulkan kontroversi. Hal itu meniscayakan analisis secara hati-hati agar kerancuan yang muncul bisa diurai. Tulisan ini sampai kepada kesimpulan bahwa pemahaman mengenai hubungan strategi dan metode tidak tunggal. Setidaknya ada lima pemahaman tentang substansi strategi dan metode pembelajaran dan bagaimana kedua istilah tersebut digunakan.

Kesimpulan tulisan ini cenderung untuk lebih menyederhanakan istilah dalam pembelajaran yang menyangkut "how". Meskipun beberapa istilah mengandung sudut pandang yang berbeda, seperti pendekatan, model, dan teknik, namun istilah metode dan strategi bisa digunakan secara saling menggantikan. Hal itu akan mempermudah bagi proses perencanaan pembelajaran dan menghilangkan polemik terhadap dua istilah yang substansinya bertumpang tindih dan sulit sekali dipisahkan. 


\section{Kepustakaan}

Budiharjo, Lily. Hakikat Metode Instruksional, (Jakarta: PAUPPAI Universitas Terbuka.

Crawford, Alan, E., Teaching and Learning Strategies for Thinking Classroom, (New York: The International Debate Education Association, 2005).

Hamalik, Oemar, Kurikulum dalam Pembelajaran, (Jakarta: Bumi Aksara, 2009).

Ismail, Strategi Pembelajaran Agama Islam Berbasis PAIKEM, (Semarang: Rasail, 2008).

Jacobsen, David A., Paul Eggen, dan Donald Kauchak, Methods for Teaching, Promoting Student Learning in K-12 Classroom, terj. Achmad Fawaid dan Khoirul Anam, (Yogyakarta: Pustaka Pelajar, 2009).

Miarso, Yusufhadi, Menyemai Benih Teknologi Pendidikan. (Jakarta: Kencana, 2007).

Munthe, Barmawie, Desain Pembelajaran, (Yogyakarta: CTSD IAIN Sunan Kalijaga, 2009).

Richard, Jack C. dan Theodore S. Rodgers, Approaches and Methodes in Language Teaching, (Cambridge: Cambridge University Press, 1999).

Riyanto, Yatim, Paradigma Baru Pembelajaran, (Jakarta: Kencana, 2010).

Sagala, Syaiful, Konsep dan Makna Pembelajaran untuk Membantu Memecahkan Problematika Belajar dan Mengajar, (Bandung: Alfabeta, 2012).

Sanjaya, Wina, Strategi Pembelajaran Berorientasi Standar Proses Pembelajaran, (Jakarta: Kencana, 2012).

Souyb, M. Joesoef, Logika: Kaidah Berpikir secara Tepat, (Jakarta: al-Husan Zikra, 1997).

Uno, Hamzah. B., Model Pembelajaran Menciptakan Proses Belajar Mengajar yang Kreatif dan Efektif, (Jakarta: Bumi Aksara, 2011).

Westwood, Peter, What Teachers Need to Know about Teaching Methods, (Victoria: ACER Press, 2008). 
Winataputra, Udin S., Model-Model Pembelajaran Inovatif. (Jakarta: PAU PPAI, 2005).

Zaini, Hisyam, Bermawie Munthe, dan Sekar Ayu Aryani, Strategi Pembelajaran Aktif, (Yogyakarta: CTSD IAIN Sunan Kalijaga, 2005). 
